\title{
INTERACTIVE WHITEBOARD IN INSTRUCTION
}

\section{Jiři DOSTÁL}

\begin{abstract}
The paper is focused on the interactive whiteboards and interactive education - teaching and learning in the information age. Interactive whiteboards are used in many schools as replacements for traditional whiteboards or flipcharts. They allow teachers to easily and rapidly create customised learning objects from a range of existing content and adapt it to the needs of the class in real time.
\end{abstract}

Key words: interactive whiteboard, education, teaching.

\section{INTERAKTIVNÍ TABULE VE VÝUCE}

Resumé: Článek pojednává o využívání interaktivních tabulí a interaktivním vzdělávání - vyučování a učení v informačním věku. Interaktivní tabule jsou v mnoha školách užívány jako alternativa $k$ tradičním bílým tabulím nebo flipchartưm. Umožňuji učiteli̛m snadno a rychle vytvořit uzpưsobené výukové objekty z řady existujicího obsahu a adaptovat je k reálným potřebám hodiny.

Klíčová slova: interaktivní tabule, vzdělávání, vyučování.

\section{Úvod}

Tradiční model výuky je stále více ovlivňován využíváním moderních technologií. V poslední době začínají být využívány ve větším měřítku interaktivní tabule. Děje se tak např́íc všemi vyučovacími předměty - jsou využívány jak při výuce prrírodopisu, zeměpisu, technické výchovy, tak i např. chemie, hudební nebo výtvarné výchovy.

Integrace interaktivních tabulí do výuky se nevyhýbá žádnému stupni vzdělávání (uplatnění nacházejí na prvním i druhém stupni základních škol, stejně tak jsou ale využívány i na středních a vysokých školách).

Interaktivní tabule jsou pro vzdělávací účely využívány ve všech vyspělých zemích, a proto se lze $\mathrm{v}$ zahraničí setkat $\mathrm{s}$ následujícími cizojazyčnými názvy: Interactive whiteboard (angl.), Tablica interaktywna (polština), Pizarra Interactiva (španělština), Lavagna Interattiva multimediale (italština), Interaktiv whiteboard (švédština), Quadro Interactivo (portugalština).

\section{Interaktivní tabule $\mathrm{z}$ technického hlediska}

$\mathrm{Z}$ technického hlediska lze interaktivní tabuli chápat jako elektronické zařízení, které je v edukační sfére využíváno ve formě materiálního didaktického prostředku. Jedná se o zařízení, které je vyvinuto speciálně pro vzdělávací účely.

Obvykle je využívána ve spojení s počítačem a dataprojektorem. Stejně tak, jako je tomu $\mathrm{v}$ prrípadě počítačové myši nebo touchpadu, získávají uživatelé interaktivní tabule jejím prostřednictvím možnost ovlivňovat činnost počítače a $\mathrm{v}$ něm spuštěných programů. Díky obrazu promítanému datovým projektorem na interaktivní tabuli (tedy tam, odkud se změny provádějí) je možné aktuální stav na výstupu počítače $\mathrm{v}$ reálném čase sledovat.

Interaktivní tabuli je možné definovat následovně:

Interaktivní tabule je dotykově-senzitivní plocha, prostřednictvím které probíhá vzájemná aktivní komunikace mezi uživatelem a počítačem s cillem zajistit maximální možnou míru názornosti zobrazovaného obsahu.

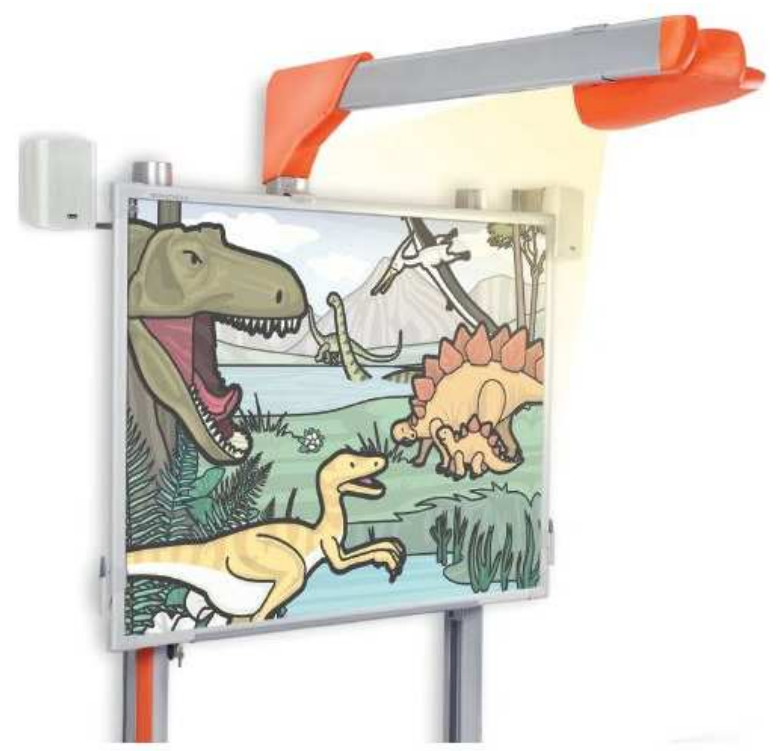

Obr. 1:Ukázka interaktivní tabule (1) 
Interaktivní tabule se ovládá prostřednictvím popisovače, stylusu (speciálního pera), přímo prstem nebo pomocí ukazovátka.

Existuje 6 základních druhů snímání pohybu, těmi se však zde nebudeme zabývat a odkazujeme čtenáře na informační zdroj (2). $\mathrm{V}$ podstatě lze od sebe rozlišit dva typy interaktivních tabulí - s přední a se zadní projekcí. V př́padě interaktivní tabule s prední projekcí je dataprojektor umístěn před tabulí. S tímto typem se setkáme v cca $99 \%$ př́padů, avšak menší nevýhodou tohoto způsobu projekce je umístění projektoru, který je vystaven možnému mechanickému poškození a navíc může být vrhán stín na tabuli během jejího užívání. Výrobci však již přicházejí s řešeními, která zkracují projekční vzdálenost a problém se stínem se tak výrazně eliminuje. Řešení problému taktéž napomáhá využívání speciálních ukazovátek.

U interaktivní tabule se zadní projekcí je datový projektor umístěn za tabulí. To odstraňuje problémy s dataprojektorem a stínem. Podstatnou nevýhodou tohoto typu je o něco vyšší cena a větší rozměry (hloubka), které mohou činit problémy při montáži přímo na stěnu.

Díky dynamickému vývoji je tradiční spojení interaktivní „tabule + dataprojektor + počítač“ stále více doplňováno o další prvky a vznikají tak interaktivní výukové systémy.

Jedním z často užívaných prvků je např. hlasovací zařízení, s jehož pomocí lze velmi rychle a přesně zjišstovat míru osvojených poznatků a žáky tak aktivně zapojovat do výuky. Těm se jednoduše zadá otázka a rázem aktivujeme i nepozorné žáky, jelikož jsou nuceni reagovat. $\mathrm{V}$ případě, že žáci neodpovídajî správně, existuje možnost díky rychlé zpětné vazbě učivo dovysvětlit. Problémem není ani export výsledků hlasování do MS Excelu.

Taktéž je možné interaktivní tabuli doplnit o bezdrátový tablet, díky kterému lze výuku vést z kteréhokoliv místa, třeba ze zadního rohu učebny. Tuto výhodu ocení zejména vyučující, kteří učí ve velkých učebnách a potřebují se pohybovat $\mathrm{v}$ prostoru. Jedná se o vstupní periferii umožňující ovládat počítač podobným způsobem jako počítačová myš, $v$ př́ípadě pera je použitelná i ke kreslení volnou rukou. Bezdrátový tablet však není určen jen učiteli, ale i žákům. Výhodou je, že v jednom čase takto může spolupracovat více žáků, samožrejmě každý na svém tabletu. Vhodné je využití tabletu pro hendikepované studenty, kteří se tak mohou plně zapojit do výuky.
$\mathrm{V}$ případech, kdy chceme využívat výhod interaktivní výuky a interaktivní tabule již „nestačí, lze využít interaktivního dotykového displeje. Na displej píšeme a kreslíme tak, jako na interaktivní tabuli a obraz je promítán na velké projekční plátno. Dotykové displeje lze využít i společně $s$ interaktivní tabulí, např̀. když vedeme výuku frontálně a nechceme se $\mathrm{k}$ žákům otáčet zády.

Interaktivní tabule jsou dodávány společně s autorským software, s jehož pomocí lze snadno naplánovat výuku a vytvářet interaktivní výukové objekty, prezentovat je a editovat. Je možné vkládat texty, obrázky, zvuky, animace, kresby atd. Autorský software obvykle obsahuje šablony a výukové objekty k volnému využití. Pro práci $\mathrm{s}$ interaktivní tabulí lze použít i výukové prezentace vytvořené v MS PowerPoint.

V praxi se setkáme i s tzv. prohližeči, což jsou, zjednodušeně řečeno, odvozeniny autorských programů, které mají zpravidla potlačenu funkci ukládání, tzn., že v prohlížeči můžeme spustit výukovou hodinu či prezentaci připravenou v plné verzi autorského softwaru. Výukové hodiny lze $\mathrm{v}$ prohlížeči volně editovat a běžně využívat, ale všechny změny, které se během výuky provedou, neuložíme.

Většina výrobců poskytuje prohlížeče zdarma a lze je instalovat na libovolný počet počítačů.

\section{Aplikace interaktivní tabule do výuky}

Jak se uvádí ve zdroji (3), učit s interaktivní tabulí umožňuje prezentovat třídě učební látku novým způsobem, dynamicky, se zvýrazněním vazeb a souvislostí a umožňuje učitelům i žákům pracovat se vzdělávacími objekty. Tímto způsobem jsou učiteli i žákům zprrístupněny rozsáhlé zdroje výukových materiálů - textů, obrázků, video i zvukových klipů, které mohou být prezentovány $\mathrm{v}$ souvislostech a vzájemných vazbách při respektování didaktických zásad.

V souvislosti s tím, jak jsou interaktivní tabule zaváděny do škol, je třeba odmítnout občas se vyskytující předsudky (byly identifikovány na základě hospitací ve výuce):

- neplatí, že by interaktivní tabule byla určena výhradně pro nékterý $z$ vyučovacích predmětù např. informatiku

Samotná interaktivní tabule je jen technickým zařízením, jehož prostřednictvím jsou při výuce využívány učební pomůcky - tj. vše, co se na interaktivní tabuli zobrazí a obsahově souvisí s výukou. Využívané výukové objekty mohou být zaměřeny na jakýkoliv vzdělávací obsah. 


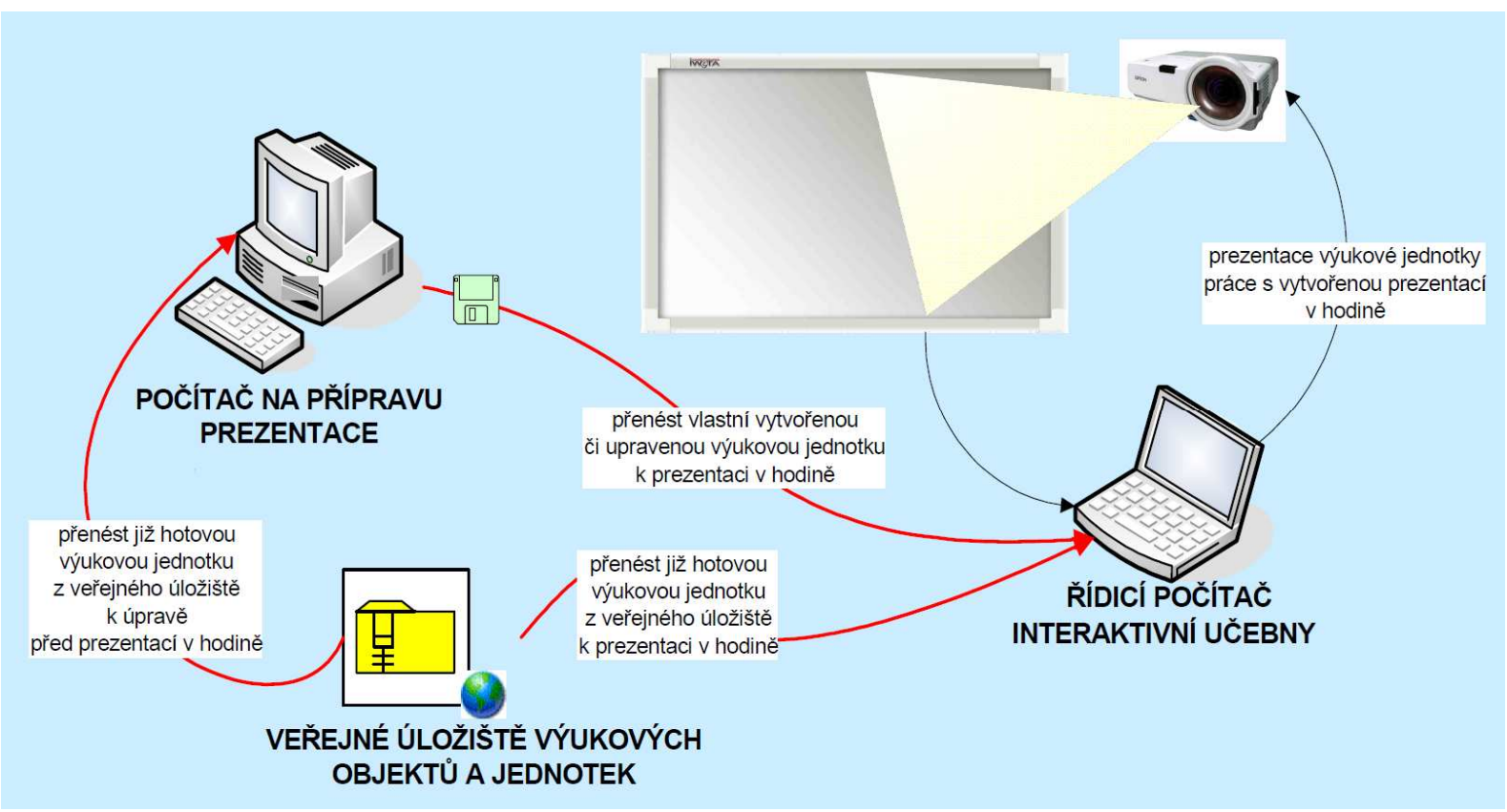

Obr. 2: Schéma znázorňující přípravu a využití interaktivních výukových hodin (upraveno dle 4)

- neplatí, že pokud chce učitel ve výuce využívat interaktivní tabuli, musí všechny výukové materiály vytvářet sám

V současnosti již existují servery, kde je možné zdarma (nebo za poplatek) stáhnout již připravené výukové hodiny - např. portál http://www.veskole.cz. Ty je možné využívat přímo (neupravené) anebo si je přizpůsobit potřebám vlastní výuky. Rovněž lze využívat tzv. i-učebnice.

- neplatí tvrzení, že pokud nemám připravené výukové objekty dopředu, nemohu interaktivní tabuli využlvat

Interaktivní tabuli je možné využívat i bez předem vytvořených výukových objektů. Řada studijních materiálů může vznikat přímo ve výuce za vzájemné spolupráce učitele a žáků. - neplatí, že by interaktivni tabule byla určena výhradně pro některou z věkových kategorii vzdělávaných

Uplatňování didaktických zásad souvisejících s interaktivními tabulemi má obecnou platnost a vztahují se na všechny věkové kategorie vzdělávaných. Využít ji lze s úspěchem na prvním stupni základní školy, tak např. i při vzdělávání dospělých.

- nelze tvrdit, že by interaktivní tabule byla určena pouze pro práci učitele

Je chybou, pokud je učitel názoru, že s interaktivní tabulí ve výuce pracuje pouze on. Nelze zapomínat na skutečnost, že aktivním zapojením do výuky se žáci efektivněji učí.
- neplatí tvrzení, že interaktivní tabuli nelze využít $v$ rámci různých výukových metod a organizačnich forem

V současném vzdělávání se využívá široká plejáda výukových metod a organizačních forem. Různí učitelé mají různé styly vyučování a bez problémů mohou interaktivní tabuli do jejich výuky integrovat, aniž by museli výrazněji měnit styl výuky (lze ji např́iklad využívat v rámci hromadné výuky, avšak stejně dobře i při individuální, projektové nebo skupinové výuce).

- nelze tvrdit, že interaktivní tabule patři jednoznačně do počítačové učebny

Někteří učitelé se stále mylně domnívají, že interaktivní tabule patří pouze do počítačové učebny. To je však zásadní omyl, naopak je vhodné její umístění v běžné třídě.

- není pravdou, že při instalaci interaktivní tabule musí být bezpodmínečně odstraněna „klasická“ tabule (křída, fixy)

$\mathrm{K}$ tomuto názoru je třeba přistupovat individuálně. Existují interaktivní tabule, které integrují několik funkcí:

1) interaktivní tabule - s možností ovládání kurzoru myši pomocí elektronického pera a tím ovládání veškerých programů a vpisování poznámek do jakéhokoliv promítaného programu,

2) bílá magnetická tabule - popisovatelná fixem smazatelným za sucha tak, jak byli učitelé dříve zvyklí (nedochází $\mathrm{k}$ poškrábání pracovní plochy, psaní křídou už je ovšem nutné opustit), 
3) kopírovací tabule - umožňují uložení textu psaného fixem do počítače.

Lze se však setkat spř́pady, kdy na projekční plochu interaktivní tabule fixou psát nejde a využívat je možné pouze, pro interaktivní tabule obvyklé, psaní speciálním perem, případně prstem (dle typu tabule). $\mathrm{V}$ těchto př́padech je vhodné ponechat ve třídě nainstalovanou i klasickou bílou tabuli, případně zvolit uspořádání, které oba dva typy kombinuje (viz následující obrázek).

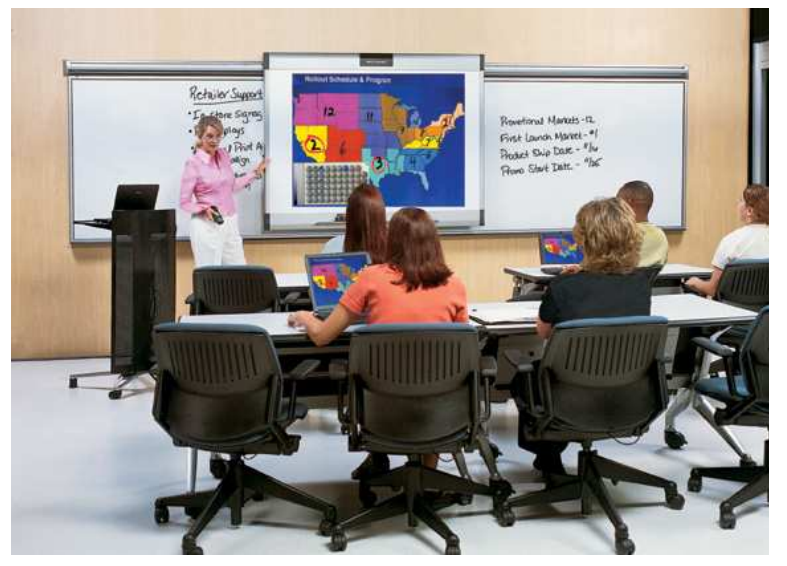

Obr. 3:Ukázka usporádání interaktivní tabule ve spojení s klasickou bílou tabulí (5)

Někteří zastánci interaktivních tabulí mají striktní názor, že kromě interaktivní tabule do třídy nic jiného nepatří. Řada učitelů se však v takovémto př́ípadě cítí handicapována a spíše vyžadují i prrítomnost klasické tabule.

- není pravda, že s interaktivní tabulí musí pracovat v daném okamžiku jen jeden uživatel,

Je velkou chybou, pokud se učitel domnívá, že stabulí se nedá pracovat kooperativně. Pokud tento způsob výuky není využíván, ztrácí interaktivní tabule na významu.

- neplatí, že interaktivní tabule musí být namontována stabilně

V řadě př́ípadů je žádoucí, aby interaktivní tabule byla mobilní. V podstatě může být kterákoliv interaktivní tabule uchycena v pojízdném rámu, což umožňuje její snadný transport do jiné třídy (učebny).

Ani při montáži „na stěnu“ nemusí být interaktivní tabule uchycena fixně - existují horizontální a vertikální posuvy. Při fixní montáži v některých případech nastává následující problém - i přesto, že je tabule umístěna $v$ nejoptimálnější výšce, musí se při psaní na dolní část větší žáci ohýbat a menší žáci naopak na její horní část nedosáhnou.
V případě vertikálního posunu je výhodou výšková nastavitelnost, v případě horizontálního posunu lze např. navíc psát na klasickou bílou keramickou tabuli tak, jak je zobrazeno na obr. č. 3. Tímto řešením se zvýší využitelnost učebny i pro ty učitele, kteří s interaktivní tabulí zrovna pracovat nechtějí.

- je velkým omylem, pokud se někdo domnivá, že interaktivní tabule není vhodná pro vzdělávání žáku se speciálními potřebami

Tabule je vhodnou pomůckou i při výuce dětí nejen s tyflopedickými, surdopedickými, ale i kombinovanými vadami. Žákům se zrakovou vadou nebo se zbytky zraku interaktivní tabule umožňuje zvětšit písmo, obrázky, grafy apod. Pokud je možné tabuli ovládat prstem, je vhodná pro žáky s poruchou jemné motoriky, jelikož se odstraní problémy obvyklé při psaní křídou, fixou či perem. Vhodná je taktéž pro imobilní žáky, kteří se mohou do výuky zapojit prostřednictvím rádiového tabletu, aniž by museli k tabuli chodit.

- není pravda, že interaktivní tabule je určena jen pro mladé učitele,

Jedná se o mylnou domněnku, zejména starších učitelů, kterou je nutné jednoznačně odmítnout. Interaktivní tabule jsou určeny všem věkovým kategoriím učitelů a naučit se s ní pracovat může opravdu každý.

\section{Výhody a nevýhody využívání interaktivních tabulí}

Jak již bylo uvedeno v publikaci (6), lze na základě řady hospitací při výuce $\mathrm{s}$ využitím interaktivní tabule vyvodit následující výhody využívání interaktivních tabulí:

- žáky lze vhodným využitím interaktivní tabule lépe motivovat $\mathrm{k}$ učení (samotná tabule to ale neumí!),

- učivo lze lépe vizualizovat, je možné využívat animace, přesouvat objekty, uplatňuje se zásada názornosti,

- lze déle udržet pozornost studentů (ale i ta po čase opadá),

- již vytvořené materiály lze využívat opakovaně (výhoda při paralelní výuce), př́padně je lze snadno upravit,

- žáky lze snadněji a aktivněji zapojit do výuky,

- text psaný přímo ve výuce lze snadno uložit a sdílet prostřednictvím internetu se studenty,

- žáci si při práci s tabulí rozvíjí informační a počítačovou gramotnost, která je pro dnešní život nezbytností,

- př́má práce s internetem (pokud je PC připojeno $\mathrm{k}$ internetu). 
Tato nová technologie má však i nevýhody, které lze shrnout následovně:

- pokud je interaktivní tabule využívána velmi často, zájem žáků opadá a berou ji jako samozrejmost,

- snadno lze sklouznout $\mathrm{k}$ encyklopedismu (tomu je možné předcházet důkladným metodickým školením učitelů),

- může být potlačován rozvoj abstraktního myšlení žáků,

- někteří učitelé ji využívají pouze jako projekční plátno (vytrácí se interaktivita),

- tvorba vlastních výukových objektů je náročná na čas a dovednosti pracovat $\mathrm{s}$ ICT,

- existuje jen málo tzv. i-učebnic (učebnic pro interaktivní tabule) a jiných již hotových výukových objektů,

- při instalaci „napevno“ chybí možnost tabuli výškově nastavit a nižší či vyšší žáci mají problémy se psaním,

- hrozí zničení nešetrným zacházením (zejména o přestávkách),

- někteří učitelé prvního stupně se vyslovují proti psaní prstem, záleží však jen na učiteli, aby byla žáky využívána pera nebo popisovače, - klasická učebnice je odsouvána do pozadí (žáci se neučí pracovat s tišš̌nou knihou),

- omezuje se psaný projev obvyklý v případě „klasické tabule“ (žáci často jen „klikají“ na tlačítka),

- některé učitele může využívání interaktivní tabule svádět $\mathrm{k}$ potlačování demonstrace reálných pokusů, přírodnin, př́ípadně jiných pomůcek,

- někteří učitelé špatně odhadují velikost písma při tvorbě učebních pomůcek, což činní problémy při čtení žákům ze vzdálenějších lavic (lze však využívat již hotové učební pomůcky),

- je nutné se naučit „pracovat“ se stínem, i když je pravdou, že existuje řada řešení, která odstran̆ují tento problém,

- při rozsvícených svítidlech anebo při intenzivním denním světle je text zobrazovaný na interaktivní tabuli špatně čitelný,

- energetická náročnost (během provozu je spotřebovávána elektrická energie, kterou musí zaplatit škola),

- tabule se může stát prostředkem šikany učitele ze strany žáků - záměrně mu rozostří dataprojektor, vypojí (přepojí) kabely mezi počítačem, dataprojektorem a interaktivní tabulí.
Nastavený trend ve vybavování škol bude mít za následek skutečnost, že se s interaktivními tabulemi budeme ve školách setkávat stále častěji. Instalací tabule do třídy však ještě není automaticky zajištěn pozitivní přínos pro vzdělávání. Velkou roli hraje přístup učitele.

Především je nutné systematicky pracovat na metodice využití interaktivních tabulí ve výuce. Doposud se lze setkat pouze s izolovanými pokusy, které mnohdy řeší pouze konkrétní problémy integrace $\mathrm{v}$ rámci jednotlivých tematických celků učiva. Nelze zapomínat na to, že $\mathrm{v}$ prrípadě interaktivních tabulí se jedná vždy o didaktickou techniku, učebními pomůckami se stávají až připravené interaktivní výukové objekty, napsané texty, vytvořené nákresy, načrtnuté grafy či diagramy - zejména na nich záleží, jak moc bude výuka efektivní.

\section{Interaktivní výuka}

V souvislosti s využíváním interaktivních tabulí je často hovořeno o interaktivní výuce. Samotný fakt, že je interaktivní tabule ve výuce př́tomna, však ještě automaticky neznamená, že se zákonitě musí jednat o interaktivní výuku. Je třeba rozlišovat, kde $\mathrm{k}$ interakci (vzájemnému působení) dochází. Jednak může docházet $\mathrm{k}$ interakci mezi uživatelem (učitelem nebo žákem) a technickým zařízením (interaktivní tabulí a počítačem), ale taktéž mezi učitelem a žáky, nebo žáky navzájem (např. výuka s využitím informačněreceptivních metod - výklad, př́ednáška aj. není př́liš interaktivní). $\mathrm{K}$ interakci mezi učitelem a žáky anebo žáky navzájem ovšem může docházet i bez interaktivní tabule, tudíž bude výuka i tak interaktivní.

Interaktivní tabule však může $\mathrm{k}$ realizaci efektivní interaktivní výuky značně přispět. Při výuce se předpokládá aktivní spoluúčast studentů zaměřená na plnění výchovněvzdělávacích cílů.

Úlohou učitele je při interaktivní výuce facilitovat - usnadňovat, umožňovat, napomáhat či podporovat. Jeho činnost spočívá i v usměrňování diskusí, zdůvodňování vhodných řešení a provázení studentů při skupinové i individuální práci.

S využitím interaktivní tabule je možné prezentovat třídě učební látku neobvyklým způsobem, dynamicky, se zvýrazněním vazeb a souvislostí. 
Jak bylo uvedeno, užívání termínu „interaktivní výuka“ může být v souvislosti s využíváním interaktivních tabulí zavádějící a proto je vhodnější používat termín „interaktivními pomůckami podporovaná výuka“.

Problémy vznikají při nazývání interaktivních produktů vytvořených pomocí autorského software. Užívat termín prezentace by nebylo zcela přesné, a proto je vhodnější používat termín ,interaktivní výukový objekt“, který lze definovat následovně:

Interaktivní výukový objekt je ucelený a didakticky zdiovodněný soubor výukových prvků (obrázků, videí, zvuků, tabulek, grafi̊ a texti̊), sestavených a do jednoho celku, který umožňuje interakci s aktéry výuky (učitelem a žáky).

\section{Závěr}

Instalace interaktivní tabule do tř́dy je jen prvním krokem, který lze oprávněně označit za ten méně podstatný. Pro realizaci efektivní výuky je důležité, aby byli kvalitně proškoleni pedagogové, kteří ji budou následně využívat v souladu s didaktickými zásadami.

Didaktickým aspektům využívání interaktivních tabulí je doposud věnována malá pozornost. Měly by se jimi věnovat vedle obecné didaktiky i oborové didaktiky a metodiky jednotlivých předmětů. Doposud se lze setkat jen s izolovanými pokusy, které mnohdy řeší konkrétní problémy integrace $\mathrm{v}$ rámci jednotlivých tematických celků učiva (7), (8), (9). ̌adu dílčích metodických materiálů lze získat na portále zaměřeném na podporu interaktivní výuky (10), inspiraci lze též načerpat v publikaci M. Hauznera a kol. (11). V zahraničí již existují ucelenější publikace metodického charakteru, např. (12), (13).

\section{Literatura}

(1) Tabule $s$ dataprojektorem $s$ krátkou projekční vzdáleností (on-line). Citováno 16. 4. 2009. Dostupné na: http://blog.svconline.com/ briefingroom/wp-content/uploads/2008/04/ smart-board-600i.JPG.

(2) Interaktivní tabule (on-line). Citováno dne 22. 8. 2009. Dostupné na http://cs.wikipedia. org/wiki/Interaktivn\%C3\%AD_tabule.

(3) Interaktivní tabule (on-line). Citováno dne 22. 8. 2009. Dostupné na http://www. zskodanska.cz/index.php?nid=3536\&lid $=\mathrm{CZ \& o}$ id=970996.
(4) Lze na interaktivní tabuli IWETA pracovat $s$ výukovými hodinami a objekty, vytvořenými $v$ prostředi SMART NOTEBOOK (on-line)? Citováno dne 22. 8. 2009. Dostupné na http://www.iweta.cz/files/smart_na_iwete.pdf.

(5) Ukázka interaktivní tabule s horizontálním posuvem (on-line). Citováno 16. 4. 2009. Dostupné na: http://interactive-av.co.uk/ largeimages/hitachi-cambridge-board-60.jpg.

(6) DOSTÁL, J. Interaktivní tabule - významný př́inos pro vzdělávání. Časopis Česká škola (online). Vydává Computer Press. Publikováno 28. 4. 2009. ISSN 1213-6018.

(7) KÁCOVSKÁ, P. Využití interaktivní tabule ve výuce př́rodopisu. In Počítač ve škole 2009. Nové Město na Moravě : GVM. 2009. CDROM. ISBN 978-80-254-3995-1.

(8) MARTINKOVÁ, A. Pracovní listy pro tvorbu učebnich pomuicek využivajicích interaktivni tabuli Smart Board. In Počítač ve škole 2009. Nové Město na Moravě : GVM. 2009. CD-ROM. ISBN 978-80-254-3995-1.

(9) Projekt SIPVZ - Interaktivní tabule na 1. stupni ZŠ. Citováno 16. 4. 2009. Dostupné na http://zskrouna.cz/projekt1.

(10) www.veskole.cz - Portál na podporu interaktivní výuky. Citováno 16. 4. 2009. Dostupné na: http://veskole.cz.

(11) HAUSNER, M. a kol. Interaktivní tabuli! Proč? Praha: ZŠ, Praha3, Lupáčova 1, 2005. 56 s. ISBN neuvedeno.

(12) GAGE, J. How to use an interactive whiteboard really effectively in your secondary classroom. London : David Fulton Publis, 2006. 139 pages. ISBN 978-1-84312-262-3.

(13) GAGE, J. How to use an interactive whiteboard really effectively in your primary classroom. London : David Fulton Publis, 2006. 128 pages. ISBN 978-1-843-12-235-7.

(14) KROTKÝ, J.. - HONZÍKOVÁ, J. Interwrite - řešení v oblasti interaktivní výuky. In INFOTECH 2007. Olomouc : Votobia, s. 587 - 589. ISBN 978-80-7220-301-7.

Jiří Dostál, PaedDr. PhDr. Ph.D.

Katedra technické a informační výchovy

Pedagogická fakulta UP

Žižkovo nám. 5

77140 Olomouc

Česká republika

telefon: +420 739249125

e-mail: j.dostal@upol.cz 